\title{
Teacher's Need in the Continuing Professional Development Program for Teachers of Vocational High School throughout Surakarta Residency
}

\author{
Tri Murwaningsih ${ }^{1}$, Hery Sawiji ${ }^{1}$, Wiedy Murtini ${ }^{1}$, Nur Rahmi Akbarini ${ }^{1}$ \\ ${ }^{1}$ Universitas Sebelas Maret \\ E-mail: nurrahmia@staff.uns.ac.id
}

\begin{abstract}
This research aimed to identify the activities needed by teachers in holding the Continuing Professional Development Program. This research employed survey type of non-experimental quantitative research method. This type of research was used when the author wants to find out the population's opinion by conducting a study on the sample of population. The population of research consisted of all teachers of Vocational High School in Business and Management field in Surakarta City Residency. The sampling technique used was purposive sampling. Techniques of collecting data were observation, interview, documentation, and questionnaire. Quantitative data obtained was the one processed using Microsoft Excel with the scale specified by the author, while qualitative data was analyzed using triangulation technique. The result of research showed that Program Continuing Professional Development had been conducted despite different proportion for self development, scientific publication, and innovative work. Thus, the appropriate strategy was required to solve some problems encountered by teachers
\end{abstract}

Keywords: teacher, professionalism, continuing professional development

\section{INTRODUCTION}

Continuing Professional Development is a program held by the government as an attempt of improving teachers' competency. The mapping of competency has been conducted through Teacher Competency Test (Uji Kompetensi Guru or UKG). UKG functions to measure basic competency concerning so that teachers will be capable of providing and also improve the quality of education in Indonesia. UKG can be used to map objective condition of individual teachers, thereby can be made some important information to government in making a policy related to material and strategy in giving building and training needed by teacher.

Mammadova \& Najafov suggested that without good preparation and strong support, the quality teaching will unlikely be achieved [1]. Because teachers are the organizer of students' learning activity [2], they are the determinant of education quality improvement at school. Goe defined teachers' quality as their qualification and characteristic affecting the teaching process and the learning outcome of students [3]. Kunter, et al.'s study found a positive effect of teachers' pedagogic content knowledge, teaching enthusiasm, and selfcontrol skill on the quality of teaching that in turn will affect the students' learning outcome [4]. This finding supports the importance of teachers' quality on students' achievement.

In Vocational High School (SMK), teacher professionalism building and development can be conducted by developing sustainable professionalism model for SMK teachers corresponding to the need for vocational education characteristic [5]. Teachers are considered professional when they have met the competency specified. The professional development is considered as one of elements supporting teacher competency in meeting the requirement of school system today [6]. This background then becomes something taken into account by the government, leading to the development of continuing professional development (CPD) policy. 
CPD is the improvement of knowledge, skill, personal and professional competency along their career [7]. CPD is getting more important to teachers in the states throughout world because the time demand requires teachers to learn sustainably [8]. Training and development give stimulant to teachers to keep developing. Training is also very important to be held for teachers to determine their qualitative characteristics [9]. CPD is important not only to teachers, but also to their institution. Belsito stated that CPD enables teachers to apply any necessary changes to the curriculum [10]. O'Brien emphasizes that continuing professional development should actually be related to the improvement of teachers' quality and students' achievement [11]. The modality different from professional development improves curricular knowledge and varying understanding in the regions, including reading comprehension and student motivation building [12].

In CPD implementation, awareness is required to meet the standard competency of teacher profession and an attempt of reforming and improving their professional competency. It is in line with Utami et al revealing that high enthusiasm and CPD participation function to be a combination effective to help teachers create their perception and willingness to put the perception onto action [13]. However, considering the result of field observation and interview, the awareness of SMK teachers in business and management throughout exSurakarta residency in implementing CPD is still low. In the last 3 (three) years, out of 20 teachers, only less than $20 \%$ have attended the sustainable professionalism development. It indicates that only very few teachers conduct self development scientific publication or produce innovative work. Time unavailability, limited personal fund, and low priority of self development are the reason of why CPD program has not run optimally yet.

Avalos conducted publication review on teacher professional development and argued that not all professional development exert positive large effect on teacher; therefore, research, experiment, and discussion are required related to teacher professional development [12]. Zakiya \& Nurhafizah argued that teacher development based on institution's need is important, but the more important one is teacher development based on individual teachers' need in order to be able to undertake professionalism process in improving their performance [14]. Considering the background, the author wants to find out what activities are actually needed by teachers in sustainable professionalism development.

\section{METHODS}

This research employed survey type of non-experimental quantitative research method. In survey-type quantitative research, the author took sample from one population and used questionnaire as an instrument of collecting primary data. The population of research consisted of all Business and Management teachers in Productive course in SMK Negeri (Public Vocational High Schools) in Surakarta Residency distributed in six regencies and one municipal. The schools are located in Surakarta Municipal, and Karanganyar, Sragen, Boyolali, Sukoharjo, Wonogiri, and Klaten Regencies.

The criterion of population was the certified teachers. There were 12 (twelve) Public Vocational High School of Business and Management in Surakarta Residency. The sample of research was taken $10 \%$ out of the population using proportional random sampling technique. Proportional random sampling was used to take the sample randomly corresponding to the proportion of respondent at school. In this research, the determination of sample size referred to Isaac and Michael with error level of $1 \%, 5 \%$, and $10 \%$ [15]. The author collected the data by distributing questionnaire. The author used questionnaire or planned interview in data collection, aiming to generalize the population based on the sample specified. In this study, the type of questionnaire used was close-ended one, in 
which the answer has been limited by the author, so that the respondents can answer the questionnaire comprehensively with their thinking. Interview was also conducted to obtain secondary data to acquire more in-depth information. Interview conducted by the author yielded response, critique, recommendation, and input related to CPD.

\section{RESULT AND DISCUSSION}

Continuing professionalism development is something requiring consideration from each of professional individuals. In education field itself, teacher profession is required to keep learning according to time development. In addition, the improvement of teacher competency also impacts on the fulfillment of credit point for grade rise. However, it is not the point, but the improvement of competency the teachers have in order to be applied through learning process in the class, thereby can affect the students comprehensively. Teacher professionalism development, particularly in Indonesia, refers to 3 aspects: (1) self development, (2) scientific publication, and (3) innovative work. In this study, data collection was conducted related to the teachers' need for CPD implementation referring to those three aspects.

The result of research conducted on Vocational High School teachers, particularly in Business and Management field, throughout Surakarta City Residence, shows that teachers' need for CPD implementation is still low in some aspects. The data was obtained from the result of questionnaires distributed to 120 teachers. Viewed from the implementation of self-development, attending functional education and training occupies the top rank with score of $18.11 \%$. It indicates that teachers have awareness of attending functional education and training. The next self development aspect is related to the need for scientific meeting, in this case each of teachers is affiliated with collective teacher activity to improve their competency and/or professionalism, with score of $14.39 \%$. It indicates that teachers feel benefiting from attending the Subject Teacher Discussion (MGMP)/Teacher Work Group (KKG) activity. It is in line with Anwar's study finding that there is a positive relationship between MGMP variable and teacher professionalism, with score of 0.527 [16]. It can be interpreted that the coefficient of correlation belongs to sufficiently strong category. If MGMP is improved, teachers' professionalism will improve, and vice versa. MGMP affects teacher performance positively; in the presence of scientific meeting, teachers can share the difficulty of teaching with each other. In addition, teachers can give input to their coworkers related to the problems encountered.

The implementation of scientific publication to teachers in this term of scientific presentation scores $10.57 \%$; the implementation of scientific publication on research results scores $7.79 \%$; meanwhile, scientific publication in the form of textbook, enrichment book, and teacher guidelines scores $13.59 \%$. From the result, it can be seen that teachers' largest need for scientific publication is related to textbook, enrichment book, and teacher guideline. Teachers are less interested in publication on research result, while they should actually keep conducting classroom action research in order to developing their professionalism sustainably. Classroom action research will expectedly have the following impacts: social change in education, change in the learning process in class, improvement of school quality and performance of education performers [17]. Wiganda stated that conducting CAR stages, teachers can find solution to the problems arising in their own class [18]. The solution to be offered includes a variety of relevant theories and learning techniques creatively. It confirms Lapeniene \& Dumciene's opinion that creative teaching concept is often used in education today [19].

The implementation of innovative work to teacher related to artwork and expedient technology invention scores $12.66 \%$. The 
implementation of innovative work to teachers related to media/visual aid preparation scores $8.87 \%$; and the implementation of innovative teachers related to question development and etc scores $14.02 \%$. From the result, it can be seen that the implementation of innovative work to teachers related to media/visual aid preparation has lowest score. It is because so far many teachers still prefer using lecturing method in teaching, and pay less attention to learning media/visual aid. Meanwhile, the use of varying learning media/visual aids will generate students' curiosity. The use of lecturing method continuously without educators' creativity will affect the students as well, in which students cannot express their opinion and explore their mind freely. Bidabadi et al.'s study found that the best teaching approach is mixed method (student- and teacher-oriented), and education plan and previous preparedness [20]. In addition, Arif Susanto also revealed the result of his research analysis related to the teachers' low capability of inventing artwork, whether independently, in group, or in institution, because not all teachers or only few teachers have interest and talent in art field. In addition, most teachers of technology-root Vocational High School still have a perception that art is not a part of their professionalism development [21]. The score (percentage) of continuing professionalism development program can be illustrated completely in the Figure 1.

In addition, an in-depth interview was also conducted with teachers of SMK in business and management field throughout Surakarta City Residency to find out what needs to do related CPD. In the term of selfdevelopment, the attempts needing to be taken are, among others, Productive Subject Education and Training OTKP K13, Vocational High School Revitalization PKB Education and Training, Modern Office Technology Training, Protocolary Training, Master of Ceremony (MC) Training, Curriculum development Education and Training, Office 365 Utilization Training in $21^{\text {st }}$ Learning, e-filling Archiving Education and Training, Entrepreneurship Education and Training, Vocation-Based Learning Education and Training, Online Business Education and Training, and Digital Communication, Technical Building of Skill Competency test Preparation, Competency Assessor Training, Education and Training concerning Class Management with Scientific Learning Approach, E-Learning Training, Learning Model Application Education and Training, and Information-Technology-Based Education and Training.

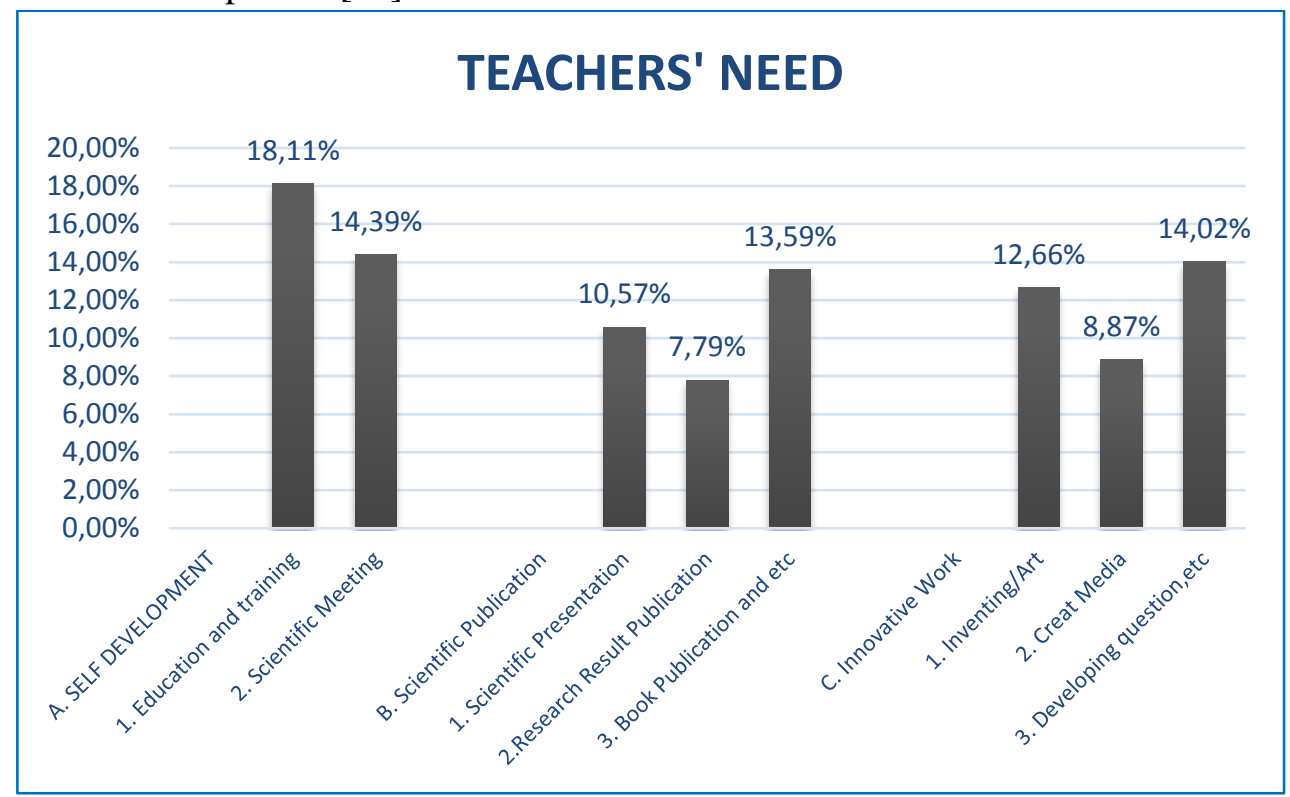

Figure 1. The score (percentage) of Teachers' Need 
Furthermore, in the term of scientific publication, the attempts needing to be taken are Education and Training of Classroom Action Research Arrangement for Vocational High School Teacher, Education and Training of Scientific Work Writing, and Training of School Exam question development. In the term of innovative works, the attempts needing to be taken are: innovative teaching material development, creative learning media development, and Education and Training of USBN (National-Standardized School Exam) Question Writing.

Along with technology development, teachers' needs are getting more complex. The need for teacher training to support this sustainable professionalism program should be prepared well in order to be appropriate-goal. It is in line with Wuryandini's study finding that the thing still needing accomplishment (perfection) is the planning about the clarity of facility to be received by training participants and the clarity of evaluation system [22]. The training held corresponding to the need will seem to be beneficial to teachers.

\section{CONCLUSION}

Professional development is considered as one of elements supporting teachers' government. Government pays very much attention to teachers' interest in self-development sustainability, so that in 2018 the Directorate General of Teacher and Education Staff organized CPD. CPD is a challenge to teachers to keep developing their competency. CPD activity involves three aspects: self-development, scientific publication, and innovative work. Vocational High School level is the one in which graduates should have competency to be competitive in work realm, so that the presence of CPD is expected to improve teachers' professionalism as a bridge to produce the highquality graduates. Science and technology development requires more complex teacher competency; thus CPD can be achieved well when training is adjusted with teachers' need.

\section{REFERENCES}

[1] S. Mammadova, "Teacher quality vs. Teaching quality," Azerbaijan J. Educ. Stud., vol. 686, no. 686, pp. 25-32, 2019.

[2] D. Melani, "PERSEPSI GURU TERHADAP PEMBINAAN KOMPETENSI PROFESIONAL GURU OLEH KEPALA SEKOLAH DI SMK SE-KECAMATAN LUBUK BEGALUNG PADANG," J. Adm. PendidikanHalaman, 3(1),381-759., vol. 3, pp. 381-759, 2015.

[3] L. Goe, "The link between teacher quality and student outcomes: A research synthesis.," Natl. Compr. Cent. Teach. Qual., 2007.

[4] M. Kunter, U. Klusmann, J. Baumert, D. Richter, T. Voss, and A. Hachfeld, "Professional competence of teachers: effects on instructional quality and student development.," J. Educ. Psychol., vol. 105, no. 3, p. 805, 2013.

[5] Muksin, "Pengembangan Model PKB (Pengembangan Keprofesian Berkelanjutan) Guru SMK di Provinsi DKI Jakarta," Autoteach, 8(2),1110-12, vol. 8, no. 02, pp. 110-123, 2016.

[6] A. Asib and S. Marmanto, "INSERVICE EFL TEACHERS'EXPERIENCES OF CONDUCTING REFLECTIVE PRACTICE AS CONTINUING PROFESSIONAL DEVELOPMENT," IJoLE, p. 52.

[7] M. Bailey, "Policy, professionalism, professionality and the development of HR practitioners in the UK," J. Eur. Ind. Train., 2011.

[8] C. Fraser, A. Kennedy, L. Reid, and S. Mckinney, “Teachers' continuing professional development: contested concepts, understandings and models," $J$. In-Service Educ., vol. 33, no. 2, pp. 153169, Jun. 2007.

[9] R. Mammadov and İ. Çimen, "Optimizing Teacher Quality Based on Student Performance: A Data Envelopment Analysis on PISA and TALIS," Int. J. Instr., vol. 12, no. 4, pp. 
767-788, Oct. 2019.

[10] C. Belsito, "The importance of "teacher quality'and 'quality teaching'on academic performance," J. Student Engagem. Educ. Matters, vol. 6, no. 1, pp. 28-38, 2016.

[11] J. O'Brien, “Continuing professional development for Scottish teachers: tensions in policy and practice," Prof. Dev. Educ., vol. 37, no. 5, pp. 777-792, 2011.

[12] B. Avalos, "Teacher professional development in teaching and teacher education over ten years," Teach. Teach. Educ., vol. 27, no. 1, pp. 10-20, 2011.

[13] I. G. A. L. P. Utami, S. Prestridge, A. Saukah, and F. A. Hamied, "Continuing Professional Development and teachers' perceptions and practices-A tenable relationship," Indones. J. Appl. Linguist., vol. 9, no. 1, pp. 108-118, 2019.

[14] Z. Maiza and N. Nurhafizah, "Pengembangan Keprofesian Berkelanjutan dalam Meningkatkan Profesionalisme Guru Pendidikan Anak Usia Dini," J. Obs. J. Pendidik. Anak Usia Dini, vol. 3, no. 2, pp. 356-465, 2019.

[15] S. Isaac and W. B. Michael, Handbook in research and evaluation: A collection of principles, methods, and strategies useful in the planning, design, and evaluation of studies in education and the behavioral sciences. Edits publishers, 1995.

[16] R. Anwar, "Pengaruh musyawarah guru mata pelajaran (MGMP) terhadap peningkatan profesionalisme dan kinerja mengajar guru sma negeri kota tasikmalaya," J. Adm. Pendidik., vol. 13, no. $1,2011$.

[17] Z. A. Ni'mah, 'Urgensi Penelitian Tindakan Kelas Bagi Peningkatan Profesionalitas Guru: Antara Cita dan Fakta," Realita, vol. 15, no. 2, pp. 1-22, 2017.

[18] S. Wiganda, "PELATIHAN PENELITIAN TINDAKAN KELAS BAGI GURU-GURU SE-JAKARTA TIMUR.," Sarwahita, vol. 11, no. 1, pp.
1-7, 2014.

[19] D. Lapeniene and A. Dumciene, "Teachers' creativity: Different approaches and similar results," Procedia-Social Behav. Sci., vol. 116, pp. 279-284, 2014.

[20] N. S. Bidabadi, A. N. Isfahani, A. Rouhollahi, and R. Khalili, "Effective teaching methods in higher education: requirements and barriers," J. Adv. Med. Educ. Prof., vol. 4, no. 4, p. 170, 2016.

[21] A. Susanto,

"Pelaksanaan Pengembangan Keprofesian Berkelanjutan (PKB) Pada Guru SMK Teknik Otomotif di Wilayah Purworejo," 2016.

[22] E. Wuryandini, "Analisis permasalahan dan kebutuhan pengembangan keprofesian berkelanjutan guru smk bidang keahlian bisnis dan manajemen pascasertifikasi di kota semarang," Manaj. Pendidik., vol. 9, no. 2, pp. 108119, 2014. 